\title{
H.J.J. BINGLE EN DIE STRYD OM CHRISTELIKE OPVOEDING EN ONDERWYS
}

\section{Oriëntering}

Dis vir my nie maklik om oor prof. dr. H.J.J. Bingle te skrywe nie omdat dit so moeilik gaan om afstand te verkry: ons was lewenslank te na aan mekaar. Hierdie verband strek van ons kinderdae af, daar in 1921 se koers, in die legendariese Karoodorpie, Venterstad. Toe ons paaie teen die einde van 1923 uiteengegaan het met die vaderlose gesin se vertrek na Steynsburg, was daar die hereniging in 1928 toe ons albei studente aan die PUK was, hy in die geesteswetenskappe en ek in die natuurweten. skappe. In 1931 het ons toe weer saam aan die voete van ons leermeester, J. Chris Coetzee, gesit. Daar het ons opvoedkundige vorming gestalte begin aanneem en dit het tot by sy aftrede in 1977 geduur en is sekerlik nooit afgesluit nie. Toe Hennie Bingle, prof. H.G. Stoker en ek eenkeer met ernstige beplanning besig was aan 'n Christelike Afrikaanse ensiklopediese kinderreeks (wat onder druk van omstandighede nie kon materialiseer nie), het hy dit pittig gestel: „Mens kan voel ons het dit saam met ons moedersmelk ingedrink".

Die voorgaande dien slegs om die probleem van afstand te beklemtoon, maar ook om die oortuiging uit te spreek dat mens iemand se werk werklik eers reg kan waardeer as jy hom ken.

\section{Bingle se loopbaan}

Gebore en getoë in 'n ortodokse maar gebalanseerde predikantsgesin, het hy van meet af aan die beginsels wat sy latere opvoedkundige aktiwiteite sou kenmerk, in suiwer vorm ont- 
vang. Soos reeds gesê, is sy akademiese vorming aan die PUK vir Christelike Hoër Onderwys begin en voltooi, 'n stempel wat deurgaans sy werk tipeer. „In U lig” het nie bloot die vrome leuse van sy Alma Mater gebly nie, maar dit het bygedra om sy eie lamp brandend te hou.

Waar hy sy onderwysloopbaan in die depressiejare (1932) moes begin, was daar ook nie vir hom te kies en te keur nie. Daar op die platteland op 'n klein skooltjie met klein kindertjies en groepklasse was die begin 'n skerp teëstelling met die einde van sy skoolloopbaan. Hy het ver in die boendoes begin, maar in die hartjie van Johannesburg geëindig, naamlik by die Hoërskool Helpmekaar. Dit herinner aan die pionierstryd om die Afrikaanse skool vir die Afrikaanse kind in die kosmopolitiese Goudstad, 'n stryd om die behoud van die eie taal, kultuur, lewensbeskouing en godsdiens. Tiperend is dan ook die feit dat hy, behalwe Geskiedenisonderwys, ook Afrikaans en Godsdiensonderrig as sy opdragte ontvang het. Veral op laasgenoemde gebiede het hy hom onderskei. As hoofeksaminator vir Afrikaans in Transvaal kon hy (en het hy ook) 'n eie stempel op die onderrig van die moedertaal afgedruk.

Dit was egter die terrein van die Godsdiensonderrig wat sy hoofbelangstelling geword het. Spoedig na sy diensaanvaarding in die onderwys het hy die behoefte aan verdere wetenskaplike vorming ervaar en met deeltydse studie vir M.Ed. begin. Hierna het die D.Ed.-studie en -graad gevolg. Sy temas was in albei studies sterk op die Godsdiensonderrig gefokus. Die titel van sy doktorale proefskrif onder promotorskap van prof. J. Chr. Coetzee was: „Enkele godsdienstige opvattinge van die middelbare skoolleerlinge; opvattinge oor 'n paar aspekte van godsdiens, oor God, die Bybel en die kerk" (1940).

Hierdie studie het deeglike onderleg in sowel die teologie as die dogmatiek vereis en die opvoedkundige bevindinge kan as prinsipieel suiwer gefundeerd bestempel word. Die neerslag hiervan in die onderwyswêreld is duidelik sigbaar.

Toe Bingle in 1945 as senior lektor in Empiriese Opvoedkunde aan die PUK aangestel is, was dit 'n versiende stap van prof. 
Coetzee. Aan 'n universiteit sou die veelsydige moontlikhede van Bingle veel meer tot hulle reg kom. Dit was die bekroning van hoogstaande akademiese en wetenskaplike prestasie, maar ook van volgehoue prinsipiële leiding op onderwysgebied en erkenning van opvoedkundige bekwaamheid. Hy moes saam met prof. Coetzee die hele spektrum van vakke vir die opleiding van sekondêre en primêre onderwysers behartig. Eers in die vyftigerjare het prof. J.J. Snyman bygekom en die Historiese Opvoedkunde plus sy aandeel aan die professionele vakke van hul skouers gehaal.

Toe prof. Chris Coetzee in 1954 as rektor benoem is, het prof. Bingle van die Empiriese Opvoedkunde oorgeskuif na die Teoretiese Opvoedkunde en die Praktiese Opvoedkunde. Hy was nou eers werklik in sy element want hy kon nou sowel prinsipiële as praktiese leiding gee, albei sake waarvoor hy besonder toegerus en geskik was.

Hy het reeds vandat prof. Coetzee as ondervoorsitter van die senaat verkies is, as dekaan van die Fakulteit Opvoedkunde opgetree (in 1952). In hierdie kapasiteit het ek onder sy leiding in 1954 begin werk. Ek bly hom dankbaar vir die leiding wat ek van hom ontvang het. In hierdie tydperk het hy ook die grondslag vir die Vergelykende Opvoedkunde gelê, sodat prof. A.G. Coetsee later daarmee kon voortgaan. Hiermee het ons universiteit sy byderwetse en bydertydse karakter duidelik getoon.

In die loop van 1961 is prof. Bingle as ondervoorsitter van die Senaat benoem en moes hy die dekaanskap neerlê. Ek wil getuig dat hy as departementshoof vir die dekaan 'n ware steunpilaar was en sy wye ervaring en nog wyer kontakte sonder voorbehoud tot beskikking van die fakulteit gestel het.

Met die aftrede van prof. J. Chr. Coetzee as rektor in 1964 was prof. Bingle die natuurlike opvolger en kon hy sonder spanninge sy ampstermyn begin. Sy werklike waarde het op die Suid-Afrikaanse opvoedkundige terrein in die wetenskaplik suiwere en in die organisatoriese vlakke gelê. Sonder om oor Bingle as rektor uit te wei, kan sonder teenspraak beweer word dat hierdie selfde twee vlakke sy belangrike bydrae tot die ontwik- 
keling van die universiteit was. Hy het intens belanggestel in sowel die didaktiese as die navorsingsaspekte van die universiteit. Daarom kon daar gedurende sy regime ook met die nuwe departement Tersiêre Onderwys begin word. Hierdie kursus is verpligtend vir alle nuwe benoemings wat nie reeds genoegsame universitêre ervaring gehad het nie. In hierdie tyd is die nuwe onderwyswet met betrekking tot onderwysersopleiding ook geimplementeer. As persoon wat die opleidingsgebeure so goed geken het, kon hy die beste vir die PU, vir die professie en vir die land beding. Hier het die PU vir CHO ook verdere baanbrekerswerk verrig, naamlik met die opleiding van sekondêre onderwysers vir 'n voorgraadse vierjarige onderwysdiploma. Die dekaan en fakulteitsraad sou seker nooit die besondere aspekte kon implementeer nie, sonder 'n rektor wat die byna unanieme personeelweerstand in die ander fakulteite doeltreffend en in goeie gees kon hanteer en tot samewerking kon ombou. Die twee nuve aspekte wat hier na vore gebring is, behels eerstens die verdeling van die gewone eerstejaar se akademiese werk in die verskillende vakdissiplines, tussen twee akademiese jare, naamlik $1 \mathrm{a}$ en $1 \mathrm{~b}$, en tweedens die aanstelling van tientalle do. sente in die verskillende fakulteite om spesiaal vir die opleiding van hierdie diplomandi verantwoordelik te wees. Juis hierom kan die PU vir CHO feitlik as die enigste inrigting beskou word waar hierdie opleiding werklik geslaagd aangepak én deurgevoer is.

Toe hy in 1977 die tuig neergelê het, was sy gees nog nie uitgeput en sy liggaam nog nie moeg nie. Sou hy die geleentheid gegun wees om sy magnum opus in die ewewigtige en inspirerende Oos-Transvaalse klimaat aan te pak en te voltooi? 